\title{
Mercury in soils of three agricultural experimental stations with long-term fertilization in China
}

\author{
Yuan-Ming Zheng ${ }^{\mathrm{a}}$, Yu-Rong Liu ${ }^{\mathrm{a}}$, Hong-Qing Hu ${ }^{\mathrm{b}}$, Ji-Zheng He ${ }^{\mathrm{a}, *}$ \\ a State Key Laboratory of Urban and Regional Ecology, Research Center for Eco-environmental Sciences, Chinese Academy of Sciences, Beijing 100085, China \\ ${ }^{\mathrm{b}}$ Key Laboratory of Subtropical Agricultural Resources and Environment, Huazhong Agricultural University, Wuhan 430070, China
}

\section{A R T I C L E I N F O}

\section{Article history:}

Received 27 September 2007

Received in revised form 7 April 2008

Accepted 16 April 2008

Available online 9 June 2008

\section{Keywords:}

Mercury

Soil

Fertilizer application

Food security

China

\begin{abstract}
A B S T R A C T
Mercury ( $\mathrm{Hg}$ ) in the agricultural ecosystem is a global concern because of its high potential toxicity. The objectives of this study were to determine the concentration and distribution of $\mathrm{Hg}$ in soils from three long-term experimental stations, i.e., Taoyuan (TY) and Qiyang (QY) in Hunan Province and Fengqiu (FQ) in Henan Province of China, and thus to assess the possible food and health risk of long-term applications of fertilizers. Soil samples at each site were collected from different fertilization plots and also from soil profiles with depths $0-100 \mathrm{~cm}$. There were significant differences in soil $\mathrm{Hg}$ concentrations in 0-20 cm (A) or 20-40 cm (B) horizon among the three experimental stations. QY station showed significantly higher $\mathrm{Hg}$ concentrations than TY and FQ stations. However, there were no significant differences in soil $\mathrm{Hg}$ concentrations between A and B horizons at each station. It was concluded that the soil $\mathrm{Hg}$ concentrations at the three sites were mainly controlled by the parent materials. Moreover, chemical fertilizer, especially phosphorous fertilizers, could influence the soil $\mathrm{Hg}$ concentrations to some extent at the station with lower soil $\mathrm{Hg}$ concentrations, for example, at TY station. There were minimal amounts of $\mathrm{Hg}$ resulting from applications of the other chemical fertilizers and organic manure, and thus the fertilization had very low risk to the food security of the agro-ecosystems in the terms of $\mathrm{Hg}$ inputs and contamination.
\end{abstract}

(c) 2008 Elsevier Ltd. All rights reserved.

\section{Introduction}

Mercury $(\mathrm{Hg})$ is a nonessential element and concerned as it is a potential neurotoxin (Zagury et al., 2006). Because of its persistence in the environment and possible toxicity to organisms, $\mathrm{Hg}$ has been listed as one of the priority pollutants by many international agencies (Jiang et al., 2006), such as United Nations Environment Programme, World Health Organization and Food and Agriculture Organization of the United Nations. Many previous studies have shown the contributions of mining and smelting activities to the concentration of $\mathrm{Hg}$ in ecosystems (FernandezMartinez et al., 2005; Kotnik et al., 2005; Feng et al., 2006; Qiu et al., 2006). Other anthropogenic activities, such as petroleum refining and fossil fuel combustion (in particular coal), industrial production processes, waste incineration, application of fungicides and land spreading of sewage sludge, are also important sources of $\mathrm{Hg}$ to the soil environment (Steinnes, 1995).

In China, the amount of $\mathrm{Hg}$ utilization has increased significantly due to the rapid development of industry and agriculture during the past two decades, for example, the use in the chloralkali production, batteries, fluorescent lamps, and fungicides

\footnotetext{
* Corresponding author. Tel.: +86 10 62849788; fax: +86 1062923563.

E-mail address: jzhe@rcees.ac.cn (J.-Z. He).
}

(Streets et al., 2005). The anthropogenic Hg emissions in China were estimated at $536( \pm 236)$ tons in 1999 (Streets et al., 2005), and total consumption of $\mathrm{Hg}$ was over 900 tons in 2000, accounting for $50 \%$ of the world production (Jiang et al., 2006). High $\mathrm{Hg}$ accumulation has been found in many ecosystems. Serious $\mathrm{Hg}$ pollution caused by wastes discharged from chemical plants occurred in some regions, such as the Songhua and Jiyun Rivers (Jiang et al., 2006). Guiyang, capital of Guizhou Province, southwest of China, has serious $\mathrm{Hg}$ contamination in the atmosphere (Feng et al. 2003). And Wanshan, located in eastern Guizhou Province, has the largest $\mathrm{Hg}$ deposition in China, where the concentrations of soil $\mathrm{Hg}$ range from 24.3 to $34.8 \mathrm{mg} \mathrm{kg}^{-1}$ (Ding et al., 2004; Jiang et al., 2006).

It has been found that many other factors, such as parent material (Rodrigues et al., 2006), organic matter (Lee et al., 1994), soil microbes (Barkay and Wagner-Dobler, 2005), played important roles in influencing the concentration and distribution of $\mathrm{Hg}$ in the soil. Clay minerals and oxides, particularly iron (Fe) and aluminium (hydr) oxides, controlled the transfer of $\mathrm{Hg}$ along soil profiles (Roulet et al., 1998). Therefore, high variability of soil Hg concentrations was closely correlated to the soil characteristics (FernandezMartinez et al., 2005; Rodrigues et al., 2006). Some of the crucial changes in soil $\mathrm{Hg}$ concentration could also be induced by the changes of land use and soil fertility (Lacerda et al., 2004; Mainville 
et al., 2006). In addition, plants could function as conduits for the interfacial transport of $\mathrm{Hg}$ from the soil to the atmosphere, and this capacity of transportation often varied according to the plant species (Leonard et al., 1998; Moreno-Jimenez et al., 2006).

However, most of the data generated from these studies were only concerned about the ecosystems polluted seriously or farmlands with no regular agricultural management practices. There is little information about the concentration and distribution of $\mathrm{Hg}$ from different agricultural soils with long-term consistent fertilizer applications. Therefore, it is necessary to reveal the status of $\mathrm{Hg}$ in agricultural soils through investigating the effects of agricultural management practices, which are vitally correlated to the security of agricultural products. The objectives of this study were to investigate the concentration and distribution of $\mathrm{Hg}$ in soils from three long-term fertilization experiments. Based on the investigation, some sources of soil $\mathrm{Hg}$ would be discussed and the possible health risk of soil $\mathrm{Hg}$ would also be assessed in agricultural ecosystems.

\section{Materials and methods}

\subsection{Study area}

Three long-term agricultural experimental stations, i.e., Taoyuan station (TY, $111^{\circ} 27^{\prime} \mathrm{E}, 28^{\circ} 55^{\prime} \mathrm{N}$ ), Qiyang station (QY, $111^{\circ} 53^{\prime} \mathrm{E}$, $26^{\circ} 45^{\prime} \mathrm{N}$ ) and Fengqiu station (FQ, $114^{\circ} 24^{\prime} \mathrm{E}, 35^{\circ} 00^{\prime} \mathrm{N}$ ), were selected for the comparison of soil $\mathrm{Hg}$ concentrations. The three long-term experiments, located at Taoyuan County, Qiyang County, and Fengqiu County, respectively, represented three different agroecosystems. TY and QY are both in Hunan Province. The annual rainfall is about $1255-1448 \mathrm{~mm}$ and the mean temperature is $16-18{ }^{\circ} \mathrm{C}$ in this region. The soil type is red soil (clay $45.0 \%$, silt $46.3 \%$ and sand $8.7 \%$ ) in QY, and paddy soil (about $40 \%$ clay) in TY. Both of them were derived from quaternary red clay earth. The long-term fertilization experiments were commenced in 1990 at these two stations. FQ is located in Henan Province and belongs to the Huang-Huai-Hai Plain, which is an important agricultural area of China with dry farming agriculture. Fengqiu County has an annual rainfall of $650 \mathrm{~mm}$ and an annual mean temperature of $13.9^{\circ} \mathrm{C}$, showing the temperate monsoon climate. The soil type is fluvo-aquic soil derived from the sediments of Yellow River. It is a typical soil in the region with a texture of sandy loam in the plough layer and loam in the subsoil. The long-term fertilization experiments were commenced in 1990.

\subsection{Experimental treatments, sampling and analytical methods}

The fertilization treatments and some basic soil chemical characteristics in the three experimental stations are listed in Table 1. There were three replicates for each treatment in TY and four replicates in QY and FQ stations. All treatments were arranged randomly and managed with long-term continuous fertilization practices for about 16 years. The soil samples were collected from all treatments at $0-20 \mathrm{~cm}(\mathrm{~A})$ in depth and some of the treatments also at $20-40 \mathrm{~cm}(B)$ in depth.

Meanwhile, at these three sites, one soil profile was set in the cropland of the experimental station without fertilization (labeled as P1) and the nearby vegetable field (labeled as P2) which usually received more intensive agricultural management (e.g., more fertilizers and pesticides) than the cropland, to examine the variation of $\mathrm{Hg}$ concentration along the soil profiles. In this way, six soil profiles, i.e., TYP1, TYP2, QYP1, QYP2, FQP1 and FQP2, were obtained. At each profile, soil samples were taken every $5 \mathrm{~cm}$ between 0 and $40 \mathrm{~cm}$ depths and every $10 \mathrm{~cm}$ between 40 and $100 \mathrm{~cm}$ depths.

Soil samples were air-dried and ground to a size finer than $0.149 \mathrm{~mm}$. Half a gram of each sample was digested with $\mathrm{HNO}_{3}+\mathrm{HCl}(10 \mathrm{ml}, 1: 1 \mathrm{v} / \mathrm{v})$ in a teflon tube with cover at $100{ }^{\circ} \mathrm{C}$ for $2 \mathrm{~h}$ (Lacerda et al., 2004; Feng et al., 2006). The total Hg concentration was then determined using an atomic fluorescence spectrometer (AFS, AFS-2202E Haiguang Analytical Instrument Co., Beijing, China). Two standard reference materials, GBW-07401 (GSS-1) and GBW-07405 (GSS-5), obtained from Center for National Standard Reference Materials of China, were inserted to the analytical process for quality assurance/quality control. The measured $\mathrm{Hg}$ concentrations of the two standard soil samples GSS- 1 and GSS-5 were $0.033 \pm 0.003 \mathrm{mg} \mathrm{kg}^{-1}(n=8)$, and $0.30 \pm$ $0.02 \mathrm{mg} \mathrm{kg}^{-1}(n=8)$, respectively, which were comparable with their certified value of $0.032 \pm 0.004 \mathrm{mg} \mathrm{kg}^{-1}$ and $0.29 \pm 0.04$ $\mathrm{mg} \mathrm{kg}^{-1}$, respectively.

\subsection{Data analysis}

Analysis of variance was performed using ANOVA with SPSS for Windows. Data were presented as mean and standard deviation for the same treatment at the same experimental site. The soil Hg concentrations of A horizons were divided by the corresponding values of $\mathrm{B}$ horizons and thus the ratios of $\mathrm{Hg}$ concentrations for these two horizons $(\mathrm{RCH})$ were obtained for further comparison.

Table 1

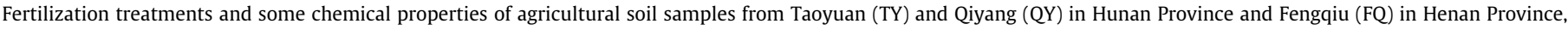
China, where the chemical fertilizers and manure applications have lasted for 16 years

\begin{tabular}{|c|c|c|c|c|c|c|c|c|}
\hline TY & Treatment & $\mathrm{CK}^{\mathrm{a}}$ & $\mathrm{NK}^{\mathrm{b}}$ & $\mathrm{NP}^{\mathrm{c}}$ & $\mathrm{NP}+\mathrm{C}^{\mathrm{d}}$ & $\mathrm{N}+\mathrm{C}^{\mathrm{e}}$ & $\mathrm{NPK}^{\mathrm{f}}$ & $\mathrm{NPK}+\mathrm{C}^{\mathrm{g}}$ \\
\hline & $\mathrm{pH} \mathrm{H}_{2} \mathrm{O}$ & $4.05 \pm 0.05$ & $4.10 \pm 0.15$ & $4.11 \pm 0.03$ & $3.98 \pm 0.03$ & $4.01 \pm 0.05$ & $4.03 \pm 0.01$ & $4.03 \pm 0.02$ \\
\hline & Organic matter $\left(\mathrm{g} \mathrm{kg}^{-1}\right)$ & $28.89 \pm 1.71$ & $30.37 \pm 6.15$ & $30.67 \pm 7.21$ & $48.60 \pm 1.43$ & $41.62 \pm 4.48$ & $35.09 \pm 3.12$ & $46.27 \pm 0.77$ \\
\hline QY & $\begin{array}{l}\text { Treatment } \\
\mathrm{pH} \mathrm{H}_{2} \mathrm{O} \\
\text { Organic matter }\left(\mathrm{g} \mathrm{kg}^{-1}\right)\end{array}$ & $\begin{array}{l}\text { CK } \\
5.47 \pm 0.18 \\
13.60 \pm 0.56\end{array}$ & $\begin{array}{l}\text { NK } \\
3.76 \pm 0.12 \\
14.32 \pm 0.52\end{array}$ & $\begin{array}{l}\text { NP } \\
3.95 \pm 0.11 \\
16.36 \pm 0.87\end{array}$ & $\begin{array}{l}\mathrm{OM}^{\mathrm{h}} \\
5.31 \pm 0.19 \\
21.74 \pm 0.07\end{array}$ & $\begin{array}{l}\mathrm{PK}^{\mathrm{i}} \\
5.03 \pm 0.14 \\
14.60 \pm 0.72\end{array}$ & $\begin{array}{l}\text { NPK } \\
4.04 \pm 0.06 \\
16.88 \pm 0.81\end{array}$ & $\begin{array}{l}\text { NPK + OM } \\
5.81 \pm 0.15 \\
21.25 \pm 0.75\end{array}$ \\
\hline FQ & $\begin{array}{l}\text { Treatment } \\
\mathrm{pH} \mathrm{H}_{2} \mathrm{O} \\
\text { Organic matter }\left(\mathrm{g} \mathrm{kg}_{-}-1\right)\end{array}$ & $\begin{array}{l}\text { CK } \\
8.77 \pm 0.04 \\
7.29 \pm 0.26\end{array}$ & $\begin{array}{l}\text { NK } \\
8.47 \pm 0.04 \\
7.45 \pm 0.23\end{array}$ & $\begin{array}{l}\text { NP } \\
8.45 \pm 0.04 \\
9.56 \pm 0.17\end{array}$ & $\begin{array}{l}\text { OM } \\
8.62 \pm 0.04 \\
16.77 \pm 0.67\end{array}$ & $\begin{array}{l}\text { PK } \\
8.67 \pm 0.04 \\
8.42 \pm 0.46\end{array}$ & $\begin{array}{l}\text { NPK } \\
8.40 \pm 0.04 \\
9.89 \pm 0.04\end{array}$ & $\begin{array}{l}\text { NPK + OM } \\
8.54 \pm 0.03 \\
12.82 \pm 0.03\end{array}$ \\
\hline
\end{tabular}

\footnotetext{
a $\mathrm{CK}=$ Control without fertilizers.

b $\mathrm{NK}=$ Nitrogen and potassium fertilizers.

c $\mathrm{NP}=$ Nitrogen and phosphorus fertilizers

${ }^{d} \mathrm{NP}+\mathrm{C}=$ Nitrogen, phosphorus fertilizers and incorporation with rice straw.

e $\mathrm{N}+\mathrm{C}=$ Nitrogen fertilizer and incorporation with rice straw.

${ }^{\mathrm{f}} \mathrm{NPK}=$ Nitrogen, phosphorous and potassium fertilizers

g $\mathrm{NPK}+\mathrm{C}=$ Nitrogen, phosphorous, potassium fertilizers and incorporation with rice straw.

h $\mathrm{OM}=$ Organic manure.

i $\mathrm{PK}=$ Phosphorus and potassium fertilizers.

j $\mathrm{NPK}+\mathrm{OM}=$ Nitrogen, phosphorous, potassium fertilizers and organic manure.
} 


\section{Results}

\subsection{Mercury concentrations in soils of the three experimental sites}

The descriptive statistics of the $\mathrm{Hg}$ concentrations in two soil horizons from different stations are shown in Table 2. The highest mean $\mathrm{Hg}$ concentration was observed in samples from QY, ranging from $0.470 \mathrm{mg} \mathrm{kg}^{-1}$ to $0.777 \mathrm{mg} \mathrm{kg}^{-1}$. Based on the ANOVA statistical analysis, the $\mathrm{Hg}$ concentrations of QY were significantly higher than those of TY and FQ, and TY significantly higher than FQ.

The mean soil Hg concentration in A horizon was higher than in B horizon in TY station while contrary trend was observed in QY station. It was found that all of RCH values in QY were smaller than 1 with mean value of 0.870 , while all of the $\mathrm{RCH}$ in TY were greater than 1 with the highest mean value of 1.380 among the three stations. The RCH of FQ showed complex variation ranging from 0.381 to 1.826 . The highest standard deviation of RCH was observed in FQ which was much higher than those in TY and QY.

\subsection{Mercury concentrations in the soils under different fertilization treatments}

Soil $\mathrm{Hg}$ concentrations of A horizon under different fertilization treatments of the three experimental stations are shown in Figs. 13. For TY (Fig. 1), the treatments of nitrogen and phosphorus fertilizers (NP) and nitrogen, phosphorus and incorporation with rice straw $(\mathrm{NP}+\mathrm{C})$ had significantly higher levels of $\mathrm{Hg}$ than the others except the treatment of nitrogen, phosphorus, potassium fertilizers and incorporation with rice straw $(\mathrm{NPK}+\mathrm{C})$, and the treatments fertilized with phosphorus except the treatment of nitrogen, phosphorus, and potassium fertilizers (NPK) had significantly higher $\mathrm{Hg}$ concentration than the treatments without phosphorous fertilizers, especially than control without fertilization (CK). For QY (Fig. 2), $\mathrm{Hg}$ concentrations in CK were higher than those in the others. However, there were no significant differences among the all treatments. For FQ (Fig. 3), $\mathrm{Hg}$ concentrations in the soils of the NPK treatment were significantly higher than the concentrations of the others. Higher concentrations of $\mathrm{Hg}$ were found in the treatments using phosphorus fertilizers compared with CK.

\subsection{Distributions of mercury along soil profiles in the three agricultural experimental stations}

The variation trend of $\mathrm{Hg}$ distribution along the soil profiles was different at the three sites (Fig. 4). In TYP1 and TYP2 the concentra-

Table 2

Total $\mathrm{Hg}$ concentrations and $\mathrm{RCH}$ values in soils of the three agricultural stations

\begin{tabular}{|c|c|c|c|c|c|c|c|}
\hline Site & Horizon & $\begin{array}{l}\text { Sample } \\
\text { number }\end{array}$ & Minimum & Maximum & Median & Mean & SD \\
\hline & & & \multicolumn{5}{|c|}{ Concentration: $\mathrm{mg} \mathrm{kg}^{-1}$} \\
\hline \multirow[t]{2}{*}{$\mathrm{TY}^{\mathrm{a}}$} & $A^{b}$ & 21 & 0.160 & 0.246 & 0.188 & 0.196 & 0.036 \\
\hline & $\mathrm{B}^{\mathrm{c}}$ & 15 & 0.126 & 0.159 & 0.140 & 0.140 & 0.012 \\
\hline \multirow[t]{2}{*}{$Q^{d}$} & A & 28 & 0.470 & 0.644 & 0.530 & 0.539 & 0.055 \\
\hline & B & 28 & 0.547 & 0.777 & 0.611 & 0.622 & 0.039 \\
\hline \multirow[t]{3}{*}{$\mathrm{FQ}^{\mathrm{e}}$} & A & 28 & 0.020 & 0.058 & 0.038 & 0.037 & 0.014 \\
\hline & B & 28 & 0.025 & 0.0520 & 0.032 & 0.035 & 0.008 \\
\hline & & & $\mathrm{RCH}^{\mathrm{f}}$ & & & & \\
\hline TY & & 15 & 1.146 & 1.740 & 1.342 & 1.380 & 0.027 \\
\hline QY & & 28 & 0.787 & 0.969 & 0.887 & 0.870 & 0.063 \\
\hline FQ & & 28 & 0.381 & 1.826 & 1.201 & 1.138 & 0.516 \\
\hline
\end{tabular}

a $\mathrm{TY}=$ Taoyuan.

b Samples from 0 to $20 \mathrm{~cm}$ depth.

c Samples from 20 to $40 \mathrm{~cm}$ depth.

d $\mathrm{QY}=$ Qiyang.

e $\mathrm{FQ}=$ Fengqiu.

${ }^{f} \mathrm{RCH}=$ ratios of soil $\mathrm{Hg}$ concentrations in A to B horizons.

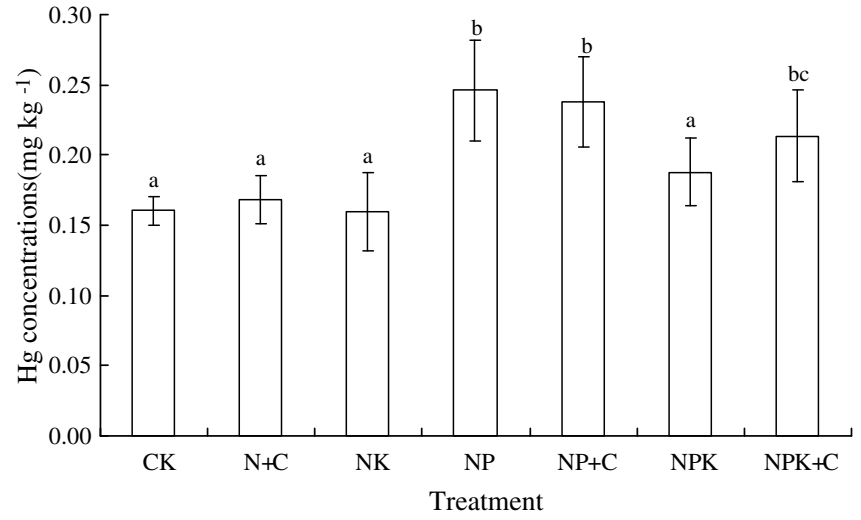

Fig. 1. Soil $\mathrm{Hg}$ concentrations in depth $0-20 \mathrm{~cm}$ under different fertilization treatments in TY station (the meanings of the treatments are present in Table 1). Different letters labeled in the figure showed the significant differences between treatments.

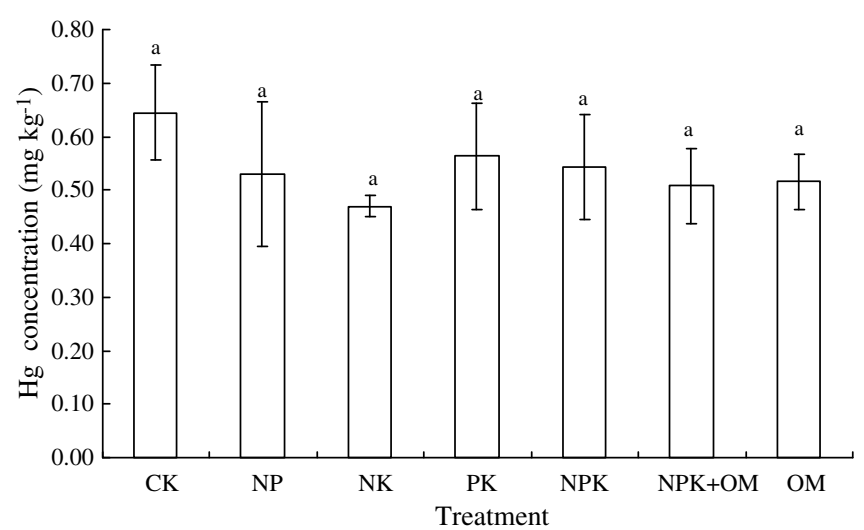

Fig. 2. Soil $\mathrm{Hg}$ concentrations in depth $0-20 \mathrm{~cm}$ under different fertilization treatments in QY station. Different letters labeled in the figure showed the significant differences between treatments.

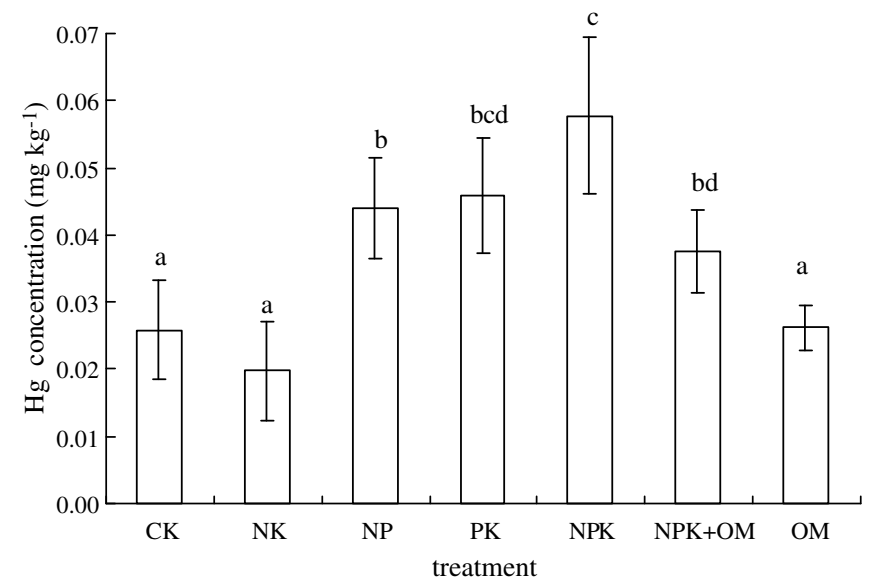

Fig. 3. Soil $\mathrm{Hg}$ concentrations in depth $0-20 \mathrm{~cm}$ under different fertilization treatments in FQ station. Different letters labeled in the figure showed the significant differences between treatments.

tions of $\mathrm{Hg}$ did not differ a lot along the soil profiles, while in FQP1 and FQP2 soil Hg concentrations tended to decrease with the profile depth. There were no significant differences between P1 and P2 in these two sites. However, soil Hg concentrations of QYP2 were significantly lower than those of QYP1. 


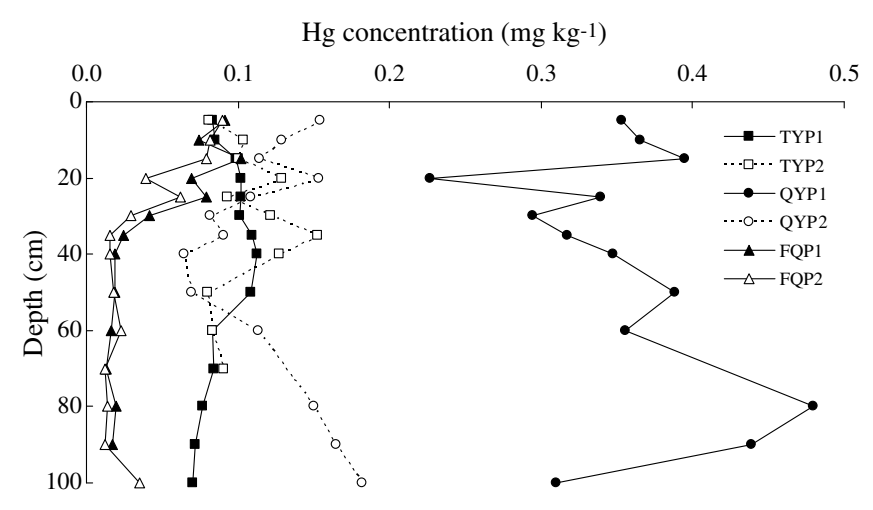

Fig. 4. Mercury distribution along soil profiles from the three experimental sites. The TYP1, QYP1 and FQP1 were the soil profiles collected from croplands without fertilization in the three experimental stations, and the TYP2, QYP2 and FQP2 were collected from vegetable lands with normal fertilization nearby the each experimental station.

\section{Discussion}

\subsection{Mercury concentration in soils under different agricultural management practices}

To some extent agricultural management practices could affect the characteristics of soil (Tomiyasu et al., 2003; Xiang et al., 2006; Manna et al., 2007). The results showed that human activities were influencing the soil $\mathrm{Hg}$ concentrations to the different extents.

Plant roots and shoots could be a reservoir of heavy metals and the biomass of plant would be related to the uptake amount of heavy metals by the plant (Moreno-Jimenez et al., 2006). In QY, mean $\mathrm{Hg}$ concentrations in maize (main crop of QY) followed the order: leaf $(81.1 \mu \mathrm{g} / \mathrm{kg})>$ root $(43.1 \mu \mathrm{g} / \mathrm{kg})>$ stem $(29.4 \mu \mathrm{g} / \mathrm{kg})$, which were 3-10 times higher than those in grains showing that biomass of plant contribute greatly to the remove of soil $\mathrm{Hg}$ from field. When collecting the samples on the site, it was observed that there was the smallest biomass of plant in CK treatment compared with the others in QY. Therefore, soil Hg concentration in CK treatment of QY was slightly higher than those in the others although all of these could hardly affect the soil Hg significantly. This phenomenon was only found in QY because of the higher soil $\mathrm{Hg}$ compared with other sites.

Moreover, fertilizers might be important sources of heavy metals in agricultural soils (Van Loon, 1974; Hutton and Symon, 1986). In this study, the analysis revealed high level of $\mathrm{Hg}\left(0.85 \mathrm{mg} \mathrm{kg}^{-1}\right)$ in the phosphorous fertilizers, which was coincided with the higher concentrations of $\mathrm{Hg}$ in the treatments fertilized with phosphorus compared with $\mathrm{CK}$ treatment in TY and FQ $(P<0.05)$. Nevertheless, there was no similar trend in the treatments of QY, which might be due to its high background level of Hg which covered up the effect of phosphorus fertilizer on the increase of $\mathrm{Hg}$ concentration, i.e., the disturbances of soil $\mathrm{Hg}$ from fertilization could only be found given the low concentrations of soil $\mathrm{Hg}$. This effect would be further discussed in the following section.

\subsection{Effects of parent materials on mercury concentration in the soils}

Soil parent material is an important factor affecting the concentration of trace metals in the soil (Kauranne, 1992) and in areas with heterogeneous lithology heavy metal concents in soils can exhibit a high variability controlled by the parent materials (Facchinelli et al., 2001), while climate factors related to the weathered process of parent rock, such as rainfall and temperature, could also contribute to the effects of parent materials on the metal level in the soil, such as $\mathrm{Hg}$ (Rodrigues et al., 2006). In this study, significant differences of $\mathrm{Hg}$ concentrations existed not only among the A horizon from the three stations, but also among the $B$ horizon (Table 2). In general, the concentrations of trace metals in B horizon were considered to be closer to the parent materials. Thus the background concentrations of $\mathrm{Hg}$ in the soil were much different in the three stations because of the big differences of the physical geographical conditions, which also meant that agricultural practices from human could not change the soil Hg to such a great extent. All of the effects mentioned in the previous section were based on the "natural" concentrations of soil Hg. Taken into account the high level of soil $\mathrm{Hg}$ in the P1 of QY, the minor variation of $\mathrm{Hg}$ concentration along the P1 also embodied the key role of parent materials clearly.

\subsection{Potential risk of the agricultural practices}

Based on the results and discussion above, it could be concluded that the concentrations of $\mathrm{Hg}$ in the soils could be controlled by several factors. Parent materials gave the original concentrations of $\mathrm{Hg}$ while human management practices disturbed the natural background. The mean RCH of TY and of FQ were greater than 1 which showed a limited trend of $\mathrm{Hg}$ accumulation in the soil, while the RCH of QY was smaller than 1 which indicated the reduction trend of $\mathrm{Hg}$ in the soil. Thus, the disturbance of human activities varied with the different agro-ecosystems. However, the effects of agricultural management practices were still much less important than the effects of soil parent materials since no significant differences were observed between the soil $\mathrm{Hg}$ concentrations of $\mathrm{A}$ and $\mathrm{B}$ horizons in the three stations.

Considering the effects of all these factors, the application of phosphorous fertilizer might influence the soil $\mathrm{Hg}$ concentrations to some extent. However, this phenomenon only emerged in the soils with lower $\mathrm{Hg}$ background. The application of other chemical fertilizers and organic manure would not significantly change the soil $\mathrm{Hg}$ concentrations in the current study. It could be concluded that there was little $\mathrm{Hg}$ accumulation risk in the soil from the long-term fertilization practices.

Table 3

Mercury concentrations in soils reported in the literature

\begin{tabular}{|c|c|c|c|c|}
\hline Soil type/land use & Location & Median/mean $\left(\mathrm{mg} \mathrm{kg}^{-1}\right)$ & Range $\left(\mathrm{mg} \mathrm{kg}^{-1}\right)$ & Reference \\
\hline Suburb soil & Shanghai, China & 0.086 & $0.031-0.169$ & Lu et al., 2006 \\
\hline Suburb soil & Nanjing, China & 0.176 & $0.122-0.233$ & Fang et al., 2002 \\
\hline Suburb soil & Wuhan, China & 0.181 & $0.006-0.447$ & Wang et al., 2005 \\
\hline Suburb soil & Taiyuan, China & 0.11 & $0.061-0.297$ & Wang et al., 2003 \\
\hline Farmland soil & Guiyang, China & 0.237 & $0.13-0.42$ & Deng et al., 2006 \\
\hline Agricultural soil & Chongqing, China & 0.096 & $0.045-0.116$ & Guo et al., 2000 \\
\hline Agricultural soil & Changjiang Delta, China & 0.587 & $0.2-1.04$ & Zhang et al., 2006 \\
\hline Agricultural soil & Zhujiang Delta, China & 0.498 & $0.16-0.84$ & Zhang et al., 2006 \\
\hline Agricultural soil & Canada & 0.04 & $0.005-0.13$ & Reimann and Caritat, 1998 \\
\hline Agricultural soil & Belgium & $0.12 / 0.24$ & $0.03-4.19$ & Tack et al., 2005 \\
\hline Background & China & 0.038 & $0.006-0.272$ & Fang et al., 2002 \\
\hline
\end{tabular}




\subsection{Comparison of soil mercury concentrations in different studies}

There was no uniform standard to assess the potential risk of soil $\mathrm{Hg}$ contamination. We attempted to show the characteristics of $\mathrm{Hg}$ distribution in soils of the three agricultural ecosystems by comparing with other agricultural soils in the world. Mercury concentrations in soil from QY station, exceeding mean $\mathrm{Hg}$ background of China a lot (CNEMC, 1990), were comparable to the concentrations in Changjiang and Zhujiang Delta (Zhang et al., 2006) and much higher than those in other cities or regions of China (Table 3). The concentrations of $\mathrm{Hg}$ in TY soils were found to be close to the concentrations of soils from Nanjing and Wuhan (Fang et al., 2002; Wang et al., 2005), which were near the Hunan Province, and had similar natural conditions. TY also had the similar soil Hg concentrations with Belgium in the agricultural soils (Tack et al., 2005). The mean concentrations in FQ were nearly equal to the mean $\mathrm{Hg}$ background concentration of China and the concentrations in agricultural soil of Canada (Reimann and Caritat, 1998). The results of comparison confirmed that total $\mathrm{Hg}$ concentrations were characterized with high variability in different locations.

\section{Conclusions}

The concentrations of soil $\mathrm{Hg}$ differed a lot among the three agricultural experimental stations with long-term fertilization practices. The order of the $\mathrm{Hg}$ concentration of A horizon in the three stations was: QY $(0.539 \pm 0.055)>\mathrm{TY}(0.196 \pm 0.036)>\mathrm{FQ}$ $(0.037 \pm 0.014)$. The effects on the concentration and distribution of $\mathrm{Hg}$ in the soils mainly came from the parent materials. The application of phosphorous fertilizers would influence, to some extent, the concentration of $\mathrm{Hg}$ in the surface soils with lower $\mathrm{Hg}$ background level. The application of the other chemical fertilizers and organic manure could not result in significant changes of soil $\mathrm{Hg}$ concentrations in the three experimental stations with longterm fertilization practice.

Since the data sets were obtained from only three experimental sites, further investigation would be necessary to confirm the factors affecting $\mathrm{Hg}$ concentrations in the soils from different agroecosystems. Moreover, it is essential to address the speciation and bioavailability of $\mathrm{Hg}$ in the soils for assessing its food and health risks.

\section{Acknowledgements}

This study was supported by the National Basic Research Program of China (2005CB121104) and the Natural Science Foundation of China (40671172, 50621804). We are grateful to X. L. Xie at the Taoyuan Station, S. W. Qin at the Fengqiu Station, and B. R. Wang and D.Z. Qin at the Qiyang Station for their assistance in soil sampling.

\section{References}

Barkay, T., Wagner-Dobler, I., 2005. Microbial transformations of mercury: potentials, challenges, and achievements in controlling mercury toxicity in the environment. Adv. Appl. Microbiol. 57, 1-52.

China National Environmental Monitoring Center (CNEMC), 1990. Background Elemental Concentrations of Chinese Soils. Environmental Science Press, Beijing, China (in Chinese), pp. 8-10.

Deng, Q.J., Song, C.R., Xie, F., He, J.L., Tan, H., Ji, Y.B., Chen, A.N., 2006. Distribution and evaluation of heavy metals in cultivated soil of Guiyang. Soils 38, 53-60 (in Chinese).

Ding, Z.H., Wang, W.H., Zai, L.Y., Tang, Q.H., Liu, C.E., Chen, J.P., Hu, W.X., 2004. Mercury pollution and its ecosystem effects in Wanshan mercury miner area, Guizhou. China J. Environ. Sci. 25, 111-114 (in Chinese).

Facchinelli, A., Sacchi, E., Mallen, L., 2001. Multivariate statistical and GIS-based approach to identify heavy metal sources in soils. Environ. Pollut. 114, 313-324.

Fang, S.B., Pan, J.J., Cheng, J.M., Chen, W., 2002. Spatio-temporal distributions of soil heavy meals in vegetable plots in Nanjing. Soil Environ. Sci. 11, 339-342 (in Chinese).
Feng, X.B., Tang, S.L., Shang, L.H., Yan, H.Y., Sommar, J., Lindqvist, O., 2003. Total gaseous mercury in the atmosphere of Guiyang, PR China. Sci. Total Environ. 304, 61-72.

Feng, X.B., Dai, Q.Q., Qiu, G.L., Li, G.H., He, L., Wang, D.Y., 2006. Gold mining related mercury contamination in Tongguan, Shaanxi Province, PR China. Appl. Geochem. 21, 1955-1968.

Fernandez-Martinez, R., Loredo, J., Ordonez, A., Rucandio, M.I., 2005. Distribution and mobility of mercury in soils from an old mining area in Mieres, Asturias (Spain). Sci. Total Environ. 346, 200-212.

Guo, C.H., Zhang, H., Yang, G.D., 2000. Mercury pollution and its control of agricultural ecosystem in heavy industry city. Agro-environ. Prot. 19, 245-247 (in Chinese).

Hutton, M., Symon, C., 1986. The quantities of cadmium, lead, mercury and arsenic entering the U.K. environment from human activities. Sci. Total Environ. 57, $129-150$.

Jiang, G.B., Shi, J.B., Feng, X.B., 2006. Mercury pollution in China. Environ. Sci. Technol. 40, 3672-3678.

Kauranne, L.K., 1992. Soil types. In: Kauranne, K., Salminen, R., Eriksson, K. (Eds.), Regolith Exploration Geochemistry in Artic and Temperate Terrains, Handbook of Exploration Geochemistry. Elsevier, New York, USA, pp. 77-92.

Kotnik, J., Horvat, M., Dizdarevic, T., 2005. Current and past mercury distribution in air over the Idrija Hg mine region, Slovenia. Atmos. Environ. 39, 7570-7579.

Lacerda, L.D., de Souza, M., Ribeiro, M.G., 2004. The effects of land use change on mercury distribution in soils of Alta Floresta, Southern Amazon. Environ. Pollut. 129, 247-255.

Lee, Y.H., Borg, G.C., Iverfeldt, A., Hultberg, H., 1994. Mercury Pollution: Integration and Synthesis. Lewis Publishers, Boca Raton, USA pp. 329-341.

Leonard, T.L., Taylor, G.E., Gustin, M.S., Fernandez, G.C.J., 1998. Mercury and plants in contaminated soil: I. Uptake, partitioning, and emission to atmosphere. Environ. Toxicol. Chem. 17, 2063-2071.

Lu, J., Cheng, J.P., Hu, X.F., Xie, H.Y., Wang, W.H., 2006. The research of mercurypolluted soil and leaves around Shanghai Wujing industrial zone. Environ. Chem. 25, 101-103 (in Chinese).

Manna, M.C., Swarup, A., Wanjari, R.H., Mishra, B., Shahi, D.K., 2007. Long-term fertilization, manure and liming effects on soil organic matter and crop yields. Soil Till. Res. 94, 397-409.

Mainville, N., Webb, J., Lucotte, M., Davidson, R., Betancourt, O., Cueva, E., Mergler D., 2006. Decrease of soil fertility and release of mercury following deforestation in the Andean Amazon, Napo River Valley, Ecuador. Sci. Total Environ. 368, 88-98.

Moreno-Jimenez, E., Gamarra, R., Carpena-Ruiz, R.O., Millan, R., Penalosa, J.M., Esteban, E., 2006. Mercury bioaccumulation and phytotoxicity in two wild plant species of Almaden area. Chemosphere 63, 1969-1973.

Qiu, G.L., Feng, X.B., Wang, S.F., Shang, L.H., 2006. Environmental contamination of mercury from Hg-mining areas in Wuchuan, northeastern Guizhou, China. Environ. Pollut. 142, 549-558.

Reimann, C., Caritat, P., 1998. Chemical Elements in the Environment: Fact Sheets for the Geochemist and Environmental Scientist. Springer, Berlin.

Rodrigues, S., Pereira, M.E., Duarte, A.C., Ajmone-Marsan, F., Davidson, C.M., Grcman, H., Hossack, I., Hursthouse, A.S., Ljung, K., Martini, C., Otabbong, E., Reinoso, R., Ruiz-Cortes, E., Urquhart, G.J., Vrscaj, B., 2006. Mercury in urban soils: a comparison of local spatial variability in six European cities. Sci. Total Environ. 368, 926-936.

Roulet, M., Lucotte, M., Saint-Aubin, A., Tran, S., Rheault, I., Farella, N., Da silva, E.D.J., Dezencourt, J., Passos, C.J.S., Soares, G.S., Guimaraes, J.R.D., Mergler, D., Amorim, M., 1998. The geochemistry of mercury in central Amazonian soils developed on the Alter-do-Chao formation of the lower Tapajos River valley, Para State, Brazil. Sci. Total Environ. 223, 1-24.

Steinnes, E., 1995. Heavy mercury. In: Alloway, B.J. (Ed.), Metals in Soils. Chapman 8 Hall, London, UK, pp. 245-259.

Streets, D.G., Hao, J.M., Wu, Y., Jiang, J.K., Chan, M., Tian, H.Z., Feng, X.B., 2005 Anthropogenic mercury emissions in China. Atmos. Environ. 39, 7789-7806.

Tack, F.M.G., Van Haesebroeck, T., Verloo, M.G., Van Rompaey, K., Van Ranst, E., 2005. Mercury baseline levels in Flemish soils (Belgium). Environ. Pollut. 134, 173-179.

Tomiyasu, T., Okada, M., Imura, R., Sakamoto, H., 2003. Vertical variations in the concentration of mercury in soils around Sakurajima Volcano, Southern Kyushu, Japan. Sci. Total. Environ. 304, 221-230.

Van Loon, J.C., 1974. Mercury input to the environment resulting from products and effluents from municipal sewage treatment plants. Environ. Pollut. 7, 141-147.

Wang, W.T., Ma, Z.D., Zhao, B., Gong, M., 2005. The concentration and distribution characteristics of mercury in Gedian area, Wuhan. Environ. Chem. 24, 454-457 (in Chinese).

Wang, Y.G., Xin, X.Y., Guo, C.H., 2003. Pollution and formation of mercury elements in the soil in Taiyuan. Chinese J. Ecol. 22, 40-42 (in Chinese).

Xiang, C.G., Zhang, P.J., Pan, G.X., Qiu, D.S., Chu, Q.H., 2006. Changes in diversity, protein content, and amino acid composition of earthworms from a paddy soil under different long-term fertilizations in the Tai Lake Region, China. Acta Ecologica Sinica 26, 1667-1673.

Zagury, G.J., Neculita, C.M., Bastien, C., Deschenes, L., 2006. Mercury fraction, bioavailability, and ecotoxicity in highly contamination soils from chlor-alkal plants. Environ. Toxicol. Chem. 25, 1138-1147.

Zhang, M.K., Fu, J.L., Gu, G.P., 2006. Chemical forms, transformation and adsorption of mercury in the soils of the Changjiang Delta and Zhujiang Delta. J. Safe Environ. 6, 1-5 (in Chinese). 